\title{
Short-term isolation of the bunchgrass steppes of the Southern Kulunda
}

\author{
Elesova N.V. \\ Altai State University, 61 Lenina prospect, Barnaul, 656049 \\ E-mail: elesovanv@mail.ru
}

Received: 14.08.2019. Accepted: 26.09.2019

\begin{abstract}
The article considers the results of the experiment to improve the condition of the degraded bunchgrass steppes of the Southern Kulunda at different stages of pasture degradation by the conservation method (2013-2018). The change in the species composition, structure of the grass stand, supply of aboveground phytomass and its components as a result of decreasing pasture load is presented.
\end{abstract}

Key words: Short-term isolation; Conservation; Bunchgrass steppe; Southern Kulunda.

\section{Introduction}

Great experience to improve the condition of degraded pastures has been accumulated in the world so far. The main measures for restoration of steppe pastures are: the establishment of an enclosure pasturing system (rotational grazing); short-term isolation from grazing (conservation); simplificated improvement with fertilizer application; creation of improved pastures by the agro-steppe method (Dzybov, 1997). The first information on the restoration of steppe pastures appeared in the middle of the 20th century (Tanfilev, 1939; Ivanov, 1958; Gorshkova A.A., Sakharovsky, 1983; Chogniy, 1988; Elesova, 1992), but all of them require large financial investments. One of the effective measures for the restoration of steppe pastures, greatly altered by increased grazing, is temporary isolation, as one of the components of rotational grazing. Conservation or short-term isolation from grazing is one of the most inexpensive ways to restore steppe pastures.

\section{Materials and Methods}

Along with studying the status of degraded steppe pastures near the Poluyamki village, Mikhaylovskiy district in May 2013, the experiment in the influence of short-term isolation (conservation) on dry bunchgrass degraded steppe was initiated. Three monitoring plots of $10 \times 10$ m corresponding to different stages of pasture degradation were selected and fenced $(\mathrm{I}-\mathrm{moderate}$ or no grazing, II - heavy grazing, III - heavy grazing - beginning of overgrazing (poaching)), located along the ecological profile towards the livestock stand.

To obtain the results we mainly used the method of comparing the indicators of the species composition abundance, structure and productivity on fenced sites and outside them, where cattle were grazed during the growing season. A more detailed description of the monitoring sites, research methods and intermediate results are given in the works of Elesova et al., 2014; Elesova, Silantyeva, 2015; Silantyeva et al., 2015; Elesova et al., 2018; indicators of the temperature and water regimes of soils are given in the works of Belyaev et al., 2017; Meissner et al., 2017.

\section{Results and Discussion}

At the beginning of the environmental profile on the fenced site I in June 2018, a true cinquefoil-koeleria-feather grass steppe (Potentilla humifusa- Koeleria cristata-Stipa capillata) was described, corresponding to the first stage of pasture degradation (moderate or no grazing). Soils are chestnut solonetz. The total projective cover (TPC) is $85-90 \%$.

The grass stand is three-layered. The first sublayer of $100 \mathrm{~cm}$ is formed by Stipa capillata, S. pennata L., Scabiosa ochroleuca L., Centaurea scabiosa L. etc. The second sublayer of $65-70 \mathrm{~cm}$ is formed by steppe Poaceae: Koeleria cristata, Poa angustifolia L., Agropyron pectinatum (Bieb.) Beauv. and steppe forbs: Galium ruthenicum Willd., Erigeron acris L., Artemisia glauca Pall. ex Willd., Salvia stepposa Shost. Festuca valesiaca Gaudin, Potentilla humifusa, P. bifurca L., Thymus marschallianus Willd., Carex supina Willd. ex Wachlend etc. are found in the third sublayer of $20-30 \mathrm{~cm}$. There are 6 species of Poaceae including: Stipa capillata, $S$. pennata, Koeleria cristata, Poa angustifolia, Agropyron pectinatum, Festuca valesiaca. There are the following legume grasses (4 species) in the grass stand: Medicago falcata L., Oxytropis pilosa (L.) DC, Onobrychis arenaria (Kit.) DC, Glycyrrhiza uralensis Fisch. The forbs group is represented by Scabiosa ochroleuca, Euphorbia virgata Waldst. et Kit., Centaurea scabiosa, Galium ruthenicum, Goniolimon speciosum (L.) Boiss., Potentilla humifusa, Potentilla bifurca, Eryngium planum L., Otites parviflora (Ehrh.) Grossh., Erygeron acris, Nonea rossica Stev., Achillea setacea Waldst., Thymus marschallianus, Convolvulus arvensis L., Berteroa incana L. etc. The steppe wormwood is represented by Artemisia austriaca Jacq., A. glauca, A. pontica L. In total, 39 species of higher vascular plants per $100 \mathrm{~m}^{2}$ are present.

On the second site, the cinquefoil-koeleria-feather grass steppe (Potentilla humifusa- Koeleria cristata- Festuca valesiaca) was described (stage II of pasture degradation - heavy grazing). Soils are dark chestnut solonetz. The TPC is $70-75 \%$.

The grass stand is three-layered. The first sublayer of $90 \mathrm{~cm}$ is formed by: Elytrigia repens (L.) Nevski, Stipa capillata, Salvia stepposa, Melilotus officinalis (L.) Pall., etc. The second sublayer of $45-50 \mathrm{~cm}$ is formed by Agropyron pectinatum, Koeleria cristata, Poa angustifolia, Festuca valesiaca, Medicago falcata and steppe forbs. Potentilla humifusa, P. bifurca, Nonea rossica, Veronica spicata L. are found in the third sublayer of $20 \mathrm{~cm}$. Poaceae are represented by Elytrigia repens, Poa angustifolia, Festuca valesiaca, Koeleria cristata, Stipa capillata, Agropyron cristatum. Legume grasses include Medicago falcata, Melilotus officinalis, Melilotoides platycarpos (L.) Sojak. Forbs group comprises Salvia stepposa, Galium ruthenicum, Berteroa incana, Centaurea scabiosa, Eryngium planum, Jacobaea erucifolia (L.) Gaertn., Nonea rossica, Achillea setacea, Potentilla humifusa, P. bifurca, P. 
canescens Bess., Scabiosa ochroleuca, Veronica spicata, Euphorbia virgata, Convolvulus arvensis, Herniaria polygama J. Gay. Steppe wormwoods are Artemisia austriaca, A. glauca, A. sieversiana Willd., A. pontica, A. commutata Bess. Sedges are represented by Carex supina. In total, 29 species of higher vascular plants per $100 \mathrm{~m}^{2}$ are identified in the grass stand.

On the third site the wormwood-alfalfa-fescue steppe was described (Artemisia austriaca-Medicago falcata-Festuca valesiaca) (stage III of pasture degradation - wormwood stage). Soils are dark chestnut solonetz. The total projective cover is $60 \%$.

There are 3 layers in the grass stand. The first sublayer of $55 \mathrm{~cm}$ is formed by: Medicago falcata, Agropyron pectinatum, Centaurea scabiosa. The second sublayer is $40-45 \mathrm{~cm}$; it features Festuca valesiaca, Artemisia austriaca, Galium ruthenicum. The third sublayer is $15-20 \mathrm{~cm}$, featuring Potentilla humifusa, P. bifurca, Astragalus testiculatus Pall. Poaceae are represented by Festuca valesiaca, Koeleria cristata, Agropyron pectinatum, Elytrigia repens. Legume grasses are Medicago falcata and Astragalus testiculatus. Forbs group is represented by Centaurea scabiosa, Potentilla humifusa, Potentilla bifurca, Berteroa incana, Galium ruthenicum, Euphorbia virgata, Achillea setacea, Chamomilla recutita (L.) Rausch, Artemisia austriaca, A. glauca. In total, 17 species of higher vascular plants per $100 \mathrm{~m}^{2}$ are present in the grass stand.

Table 1. Effect of short-term isolation on the supply of aboveground phytomass of dry bunchgrass steppe (moderate grazing stage feather grass stage).

\begin{tabular}{lcccccc}
\hline \multicolumn{1}{c}{ Year } & $\mathbf{2 0 1 3}$ & $\mathbf{2 0 1 4}$ & $\mathbf{2 0 1 5}$ & $\mathbf{2 0 1 6}$ & $\mathbf{2 0 1 7}$ & $\mathbf{2 0 1 8}$ \\
$\begin{array}{l}\text { Above the } \\
\text { ground }\end{array}$ & 307.5 & 277.88 & 596.4 & 354.1 & 681.2 & 693.1 \\
$\begin{array}{l}\text { phytomass } \\
\text { Green }\end{array}$ & 207.4 & 215.67 & 415.4 & 218.5 & 520.8 & 391.6 \\
$\begin{array}{l}\text { shoots } \\
\begin{array}{l}\text { Dead grass } \\
\text { Ground }\end{array}\end{array}$ & 2.11 & 13.31 & 12.5 & 40.0 & 46.4 & 87.3 \\
litter & 87.73 & 48.9 & 168.5 & 95.6 & 114.0 & 214.2 \\
\hline
\end{tabular}

Table 2. Effect of short-term isolation on the supply of aboveground phytomass of dry bunchgrass steppe (stage of heavy grazing fescue stage).

\begin{tabular}{lcccccc}
\hline \multicolumn{1}{c}{ Year } & $\mathbf{2 0 1 3}$ & $\mathbf{2 0 1 4}$ & $\mathbf{2 0 1 5}$ & $\mathbf{2 0 1 6}$ & $\mathbf{2 0 1 7}$ & $\mathbf{2 0 1 8}$ \\
$\begin{array}{l}\text { Above the } \\
\text { ground }\end{array}$ & 178.84 & 157.56 & 286.0 & 319.9 & 524.6 & 582.6 \\
$\begin{array}{l}\text { phytomass } \\
\begin{array}{l}\text { Green } \\
\text { shoots }\end{array}\end{array}$ & 101.55 & 109.9 & 204.0 & 174.5 & 413.6 & 340.0 \\
$\begin{array}{l}\text { Dead grass } \\
\text { Ground litter }\end{array}$ & 3.53 & 3.83 & 9.7 & 48.8 & 23.6 & 48.2 \\
\hline
\end{tabular}

Table 3. Effect of short-term isolation on the supply of aboveground phytomass of dry bunchgrass steppe (stage of heavy grazing overgrazing stage - wormwood stage).

\begin{tabular}{lcccccc}
\hline \multicolumn{1}{c}{ Year } & $\mathbf{2 0 1 3}$ & $\mathbf{2 0 1 4}$ & $\mathbf{2 0 1 5}$ & $\mathbf{2 0 1 6}$ & $\mathbf{2 0 1 7}$ & $\mathbf{2 0 1 8}$ \\
$\begin{array}{l}\text { Aboveground } \\
\text { phytomass }\end{array}$ & 62.3 & 67.75 & 176.7 & 167.1 & 272.8 & 444.8 \\
$\begin{array}{l}\text { Green } \\
\text { shoots }\end{array}$ & 30.6 & 37.2 & 113.6 & 80.4 & 173.6 & 307.6 \\
$\begin{array}{l}\text { Dead grass } \\
\text { Ground litter }\end{array}$ & 0.43 & 1.55 & 8.4 & 16.5 & 23.6 & 25.2 \\
\hline
\end{tabular}

Short-term isolation positively affected the supply value of all components of the aboveground phytomass (Tables 1-4). At the moderate grazing stage (Potentilla humifusa- Koeleria cristata-Stipa capillata) in July 2018, the total supply of aboveground phytomass increased slightly from 521.6 to $693.1 \mathrm{~g} / \mathrm{m}^{2}$, the productivity of green shoots increased from 363.2 to $391.6 \mathrm{~g} / \mathrm{m}^{2}(\mathrm{Tables}$ $1,3)$ due to an increase in the proportion of Poaceae. The share of dead grass increased 4.7 times, ground litter supply increased 1.5 times (from 140 to $214.2 \mathrm{~g} / \mathrm{m}^{2}$ ). It should be noted that such a significant increase in the supply of aboveground phytomass in 2018 is explained not only by the influence of isolation, but also by heavy precipitation.

Table 4. Effect of conservation on the main indicators of dry bunchgrass steppe (Mikhaylovskiy district, precincts of the Poluyamki village, $07 / 13 / 2018, \mathrm{~g} / \mathrm{m}^{2}$ ).

\begin{tabular}{|c|c|c|c|c|c|c|c|c|c|}
\hline Site & Association & $\begin{array}{l}\text { Numbe } \\
\text { r of } \\
\text { layers }\end{array}$ & Height & $\begin{array}{l}\text { Num } \\
\text { ber } \\
\text { of } \\
\text { speci } \\
\text { es }\end{array}$ & TPC & $\begin{array}{l}\text { Abovegr } \\
\text { ound } \\
\text { phytoma } \\
\text { ss }\end{array}$ & $\begin{array}{l}\text { Green } \\
\text { shoots }\end{array}$ & $\begin{array}{l}\text { Dead } \\
\text { grass }\end{array}$ & $\begin{array}{l}\text { Ground } \\
\text { litter }\end{array}$ \\
\hline I & $\begin{array}{c}\text { Cinquefoil- } \\
\text { koeleria-feather } \\
\text { grass }\end{array}$ & 3 & 100 & 39 & $85-90$ & 693.1 & 391.6 & 87.3 & 214.2 \\
\hline II & $\begin{array}{c}\text { Cinquefoil- } \\
\text { koeleria -fescue }\end{array}$ & 3 & 970 & 29 & $70-75$ & 582.6 & 340.0 & 48.2 & 194.4 \\
\hline III & $\begin{array}{l}\text { Wormwood- } \\
\text { alfalfa-fescue }\end{array}$ & 3 & 55 & 17 & 60 & 444.8 & 307.6 & 25.2 & 112.0 \\
\hline
\end{tabular}

The total number of species on site I (moderate grazing) increased slightly during 6 years of isolation (we registered 39 plant species within the site lines and 29 outside the lines). An increase in the vitality and abundance of edificators (Stipa capillata, Stipa pennata, 
Medicago falcata) in an isolated area, which manifested itself in their height, number of individuals, and the number of generative shoots was noted.

For 6 years of isolation, the structure of the grass stand has undergone significant changes in the direction of improvement. The number of sublayers has increased to 3, the height of the first sublayer has risen by $15 \mathrm{~cm}$, TPC has increased by $20 \%(85-90 \%$ and $65-70 \%$, respectively).

At the stage of heavy grazing (II - fescue stage), short-term isolation also positively affected the value of the aboveground phytomass supply (Potentilla humifusa- Koeleria cristata- Festuca valesiaca) of the steppe. The total aboveground phytomass supply increased from 300 to $582.6 \mathrm{~g} / \mathrm{m}^{2}$ (Tables 1 -4). Additionally, the share of green shoots almost doubled (from 195.0 to 340.0 $\mathrm{g} / \mathrm{m}^{2}$ ) mainly due to an increase in the share of Poaceae and Medicago falcata; the share of dead grass grew 14 times from 3.4 to $48.2 \mathrm{~g} / \mathrm{m}^{2}$; the ground litter share almost doubled from 101.6 to $194.4 \mathrm{~g} / \mathrm{m}^{2}$ (Tables 1-4).

It is worth noting that the role of Poaceae (Koeleria cristata) and legume grasses increases in the structure of green shoots with short-term isolation, the proportion of forbs does not change significantly. In an isolated area, the projective cover of Medicago falcata increases from 3 to $10 \%$, it becomes one of the edificators of the grass stand; new plant species appear: Artemisia canescens, Artemisia commutata, Astragalus onobrychis. On an isolated site, the grass stand is three-layered, its height is $90 \mathrm{~cm}$, the projective cover is $70-75 \%$, on the grazed area, the height of the grass is $70 \mathrm{~cm}$, the TPC is $55-60 \%$. The vitality of the grass stand edificator - Koeleria cristata improved (its projective cover increased 3 times from 5 to 15\%); in Festuca valesiaca, the projective cover remains fairly high (15\% and $18 \%$, respectively).

On the third plot (heavy grazing - the beginning of overgrazing, wormwood stage) in the steppe isolated area (Artemisia austriacaMedicago falcata-Festuca valesiaca), an increase of aboveground phytomass supply by 2.7 times was also noted (from 97.0 to $272.8 \mathrm{~g} / \mathrm{m}^{2}$ ). The share of green shoots increased 2.3 times from 190.8 to $444.8 \mathrm{~g} / \mathrm{m}^{2}$ due to the proportion of legume grasses and forbs, the share of Poaceae remained the same. Ground litter supply increased from 70.2 to $112.0 \mathrm{~g} / \mathrm{m}^{2}$. Dead grass supply increased 9 times from 2.6 to $25.2 \mathrm{~g} / \mathrm{m}^{2}$.

In the isolated area, we observed an increase in the number of plant species, which was 17 (compared to 10 in the grazed area), mainly due to forbs: Artemisia glauca, Artemisia commutata, and Astragalus testiculatus, as for legume grasses. A greener aspect is observed, the vitality of Festuca valesiaca and Medicago falcata improved, which manifested itself in an increase in the height and number of generative shoots absent in the grazed areas of the fescue-wormwood strongly degraded steppe.

The structure of the grass stand underwent significant changes in the direction of improvement: the height of the first layer increased

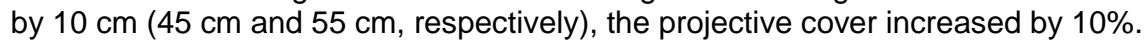

\section{Conclusion}

Our experiment in the short-term isolation of areas of the true bunchgrass steppe being at different stages of degradation, in the conditions of the dry steppe zone of Kulunda during 6 growing seasons allowed us to draw the following conclusions:

- the steppes of the Southern Kulunda degraded as a result of overgrazing have a sufficient supply of seeds of the main forage plants species, which is manifested in an increase in the productivity of the grass stand in some months with a sufficient or increased supply of moisture;

- in conditions of a sufficient supply of moisture, dead grass and ground litter supply in heavily degraded areas can quickly restore in case of conservation;

- isolation contributes to the improvement of the pasture communities structure: layerage is restored, the total projective cover increases;

- temporary isolation contributes to an increase in the supply of aboveground phytomass and its components and is an effective method of the steppe pastures restoration.

Thus, temporary isolation is an effective method of restoration of steppe pastures located at intermediate degradation stages. Complete restoration of heavily poached pastures requires a longer period, depending on the moisture regime of the studied area.

\section{References}

Belyaev, V.I., Bondarovich, A.A., Ponkina, E.V., Scherbinin, V.V., Schmidt, G., Matsyura, A.V., Kozhanov, A.A., Rudev, N.V. (2017). The temperature regime of air and soil according to the meteorological and soil-hydrological monitoring network in the Kulundinskaya plain for the growing season 2013-2016. Bulletin of Altai State Agrarian University, 3 (149), 30-36. (In Russian).

Chogniy, O. (1988). Phytocenotic basis for improving the natural forage lands of the MPR. Moscow. (In Russian).

Gorshkova, A.A., Sakharovsky, V.M. (1983). Restoration of poached steppe pastures during their short-term isolation. Agricultural Science Bulletin, 4. (In Russian).

Dzybov, D.S. (2010). Agro-steppes. Stavropol, AGRUS. (In Russian).

Elesova, N.V. (1992). Conservation as a way of preserving and restoring steppe pastures. State and ways of saving the gene pool of wild plants and animals in Altai Territory. Proceed. Sc. Conf. Barnaul, Publishing house of ASU. (In Russian).

Elesova, N.V., Silantyeva, M.M., Speranskaya, N.Yu., Grebennikova, A.Yu. (2014). Assessment and possible ways of the degraded pasture restoration in the dry steppe conditions of Kulunda. Bulletin of Altai Science, 1, 223-228. (In Russian).

Elesova, N.V., Silantyeva, M.M. (2015). The influence of short-term isolation on the vegetation of degraded pastures in Southern Kulunda. Steppes of Northern Eurasia. Proceed. VII Int. Sym. Orenburg, Dimur. (In Russian).

Elesova, N.V., Silantyeva, M.M., Kornyevskaya, T.V. (2018). Ways of degraded pastures restoration in the conditions of the dry steppe zone of Kulunda. Steppes of Northern Eurasia. Proceed. VIII Int. Sym. Orenburg. (In Russian).

Ivanov, V.V. (1958) Steppes of Western Kazakhstan in connection with the dynamics of their cover. Moscow - Leningrad. (In Russian).

Meissner, R., Rupp, H., Bondarovich, A.A., Rinklebe, S. (2017). Soil water management in the Siberian Kulunda-dry steppe. Mechanization in Agriculture \& Conserving of the Resaurces, 5, 197-201.

Silantyeva, M.M., Kharlamova, N.F., Elesova, N.V., Speranskaya, N.Yu., Galtsova, T.V., Solomonova, M.Yu., Kurepina, N.Yu., Grebennikova, A.Yu., Plutalova, T.G. (2015). Restoration of the steppe ecosystems of the dry steppe zone of Kulunda taking into account the historical reconstruction of the vegetation cover. Bulletin of Altai Science, 1 (23), 241-245. (In Russian).

Tanfilev, G.I. (1939). On the effect of grazing on the steppe Poaceae. (In Russian).

\section{Citation:}

Elesova N.V. (2019). Short-term isolation of the bunchgrass steppes of the Southern Kulunda. Ukrainian Journal of Ecology, 9(3), 360-362.

(cc) $\mathrm{Er}$ This work is licensed under a Creative Commons Attribution 4.0. License 